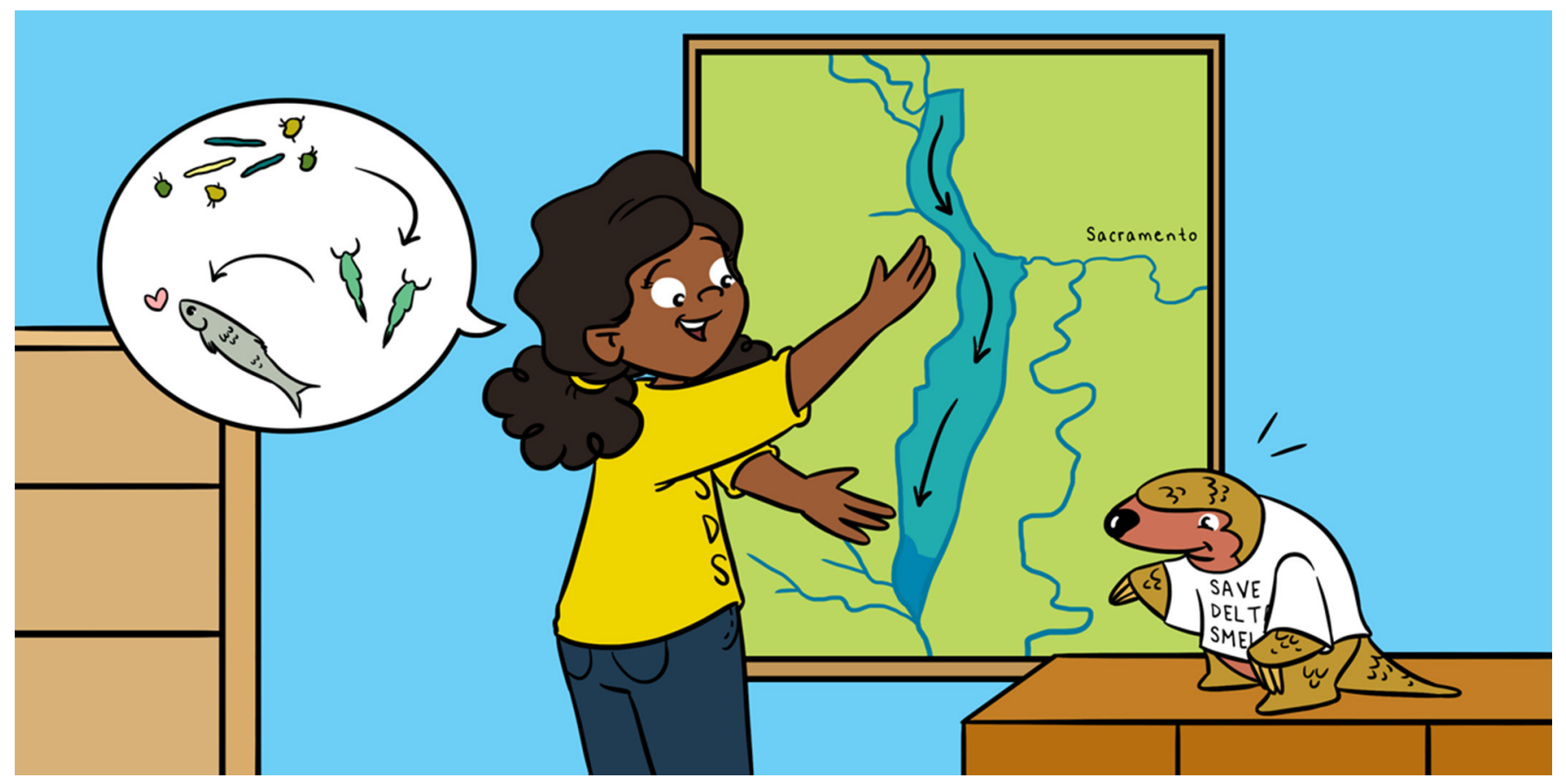

\title{
DELIVERING FOOD TO HUNGRY FISH IN THE SAN FRANCISCO ESTUARY
}

\section{Laura Twardochleb ${ }^{1 *}$, Leela Dixit ${ }^{1}$, Mallory Bedwell ${ }^{1}$, Brittany Davis ${ }^{1}$ and Jared Frantzich ${ }^{2}$}

${ }^{1}$ Ecosystem Monitoring, Research, \& Reporting Branch, Division of Integrated Science and Engineering, California Department of Water Resources, West Sacramento, CA, United States

${ }^{2}$ North Central Regional Office, Division of Regional Assistance, California Department of Water Resources, West Sacramento, CA, United States

\section{YOUNG REVIEWERS:}

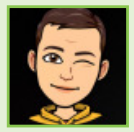

DARIO

AGE: 14

VALERIE

AGE: 13
The San Francisco Estuary is home to an important endangered fish called delta smelt. Delta smelt eat small, nutritious animals called zooplankton to survive and grow. In turn, zooplankton grow by eating microscopic plant-like organisms called phytoplankton. In the past, the Estuary was full of plankton and delta smelt. Because people have removed water from the Estuary and invasive species now live there, the Estuary no longer has enough plankton to feed delta smelt, making it difficult for them to survive. Scientists have found a unique place in the Estuary, the Yolo Bypass, that has lots of fish food. The problem is that delta smelt do not live in the Yolo Bypass year-round. Scientists are working to solve this problem by sending river or farm water through the Yolo Bypass, to move fish food downstream to feed the hungry delta smelt and other fish species. 


\section{ZOOPLANKTON}

Small animals that drift in the water current.

PHYTOPLANKTON

Microscopic organisms that grow by

harnessing energy from sunlight just like plants.

FOOD WEB

A set of crossing food chains representing feeding relationships among organisms.

\section{INVASIVE SPECIES}

Animals and plants introduced by humans that disturb the ecosystem when the population reaches large numbers.

TIDAL MARSH

A wetland found along rivers, coasts, and estuaries that floods and drains with the movement of the tides.

\section{FLOODPLAIN}

An area of land next to a river that floods when the river is high.

\section{ECOSYSTEM}

A community of living organisms interacting with the non-living components of their environment.

\section{UNHEALTHY ESTUARY MEANS LESS FOOD FOR FISH}

The San Francisco Estuary is home to many species of native fish and large numbers of plankton, which are tiny organisms that live in the water. Some fish species in the Estuary, such as delta smelt, are found nowhere else in the world. Plankton species that live in the Estuary include very small animals called zooplankton, which fish need to eat to survive, grow, and reproduce. Zooplankton eat even tinier organisms called phytoplankton, which are microscopic organisms that grow by harnessing energy from sunlight just like plants. This is an example of a food chain (Figure 1), and lots of crossing food chains make a food web. Since the 2000s, scientists have noticed that plankton have been decreasing in the Estuary, which has led to declines in the populations of several fish species [1, 2]. This is happening because the San Francisco Estuary is not as healthy as it used to be, and it all began a long time ago!

In the mid-1800s, many thousands of people rushed to California to search for gold during the Gold Rush. Since then, the San Francisco Estuary has changed a lot. People built in and around the Estuary and brought in invasive species (Figure 2) [3]. Since the 1950s, people have removed large amounts of water from rivers draining the Estuary, for farming and for use by people living in cities. Developing the landscape and removing water destroyed tidal marshes and floodplains, which fish and plankton need to feed, grow, and reproduce. Invasive species have made matters worse by occupying areas where native species live and competing with native species for plankton. As a result, there is less plankton to feed native fish, like the endangered delta smelt [2].

\section{WHY ARE DELTA SMELT IMPORTANT AND WHAT DO THEY EAT?}

Delta smelt are small fish, about the length of a chicken egg, that exist only in certain parts of the San Francisco Estuary. They live for just 1 year, and their unique life cycle makes them especially sensitive to changes in their environment. Because of their sensitivity, delta smelt are considered indicators of ecosystem health, meaning that they tell us how healthy or unhealthy the San Francisco Estuary is. For example, large numbers of delta smelt in the Estuary indicate that the Estuary is healthy. In the 2000s, the number of delta smelt in the Estuary declined so much that they are now at risk of extinction [2], which tells us that something is wrong with the ecosystem. Like many other fish species in the Estuary, delta smelt eat zooplankton, which in turn eat phytoplankton. Delta smelt populations are declining in part because there is not enough plankton in the Estuary [2].

\section{WHERE IN THE ESTUARY DO DELTA SMELT LIVE?}

Delta smelt spend part of their lives in the freshwater portion of the Estuary, a place called the Sacramento-San Joaquin Delta. Before 
Figure 1

Phytoplankton are eaten by zooplankton, which are the favorite prey of the endangered delta smelt. When there are lots of

phytoplankton in the San Francisco Estuary, zooplankton eat more and grow in numbers. When there are more zooplankton, delta smelt have more food to eat, which helps them to survive, grow, and reproduce. Scale bars show the length of each organism. [Photo credits: delta smelt photo by B. Moose Peterson (USFWS), zooplankton photo by Jeff Cordell (USGS), and phytoplankton photo by Alexander Klepnev (licensed under Creative Commons Attribution 4.0 International)].

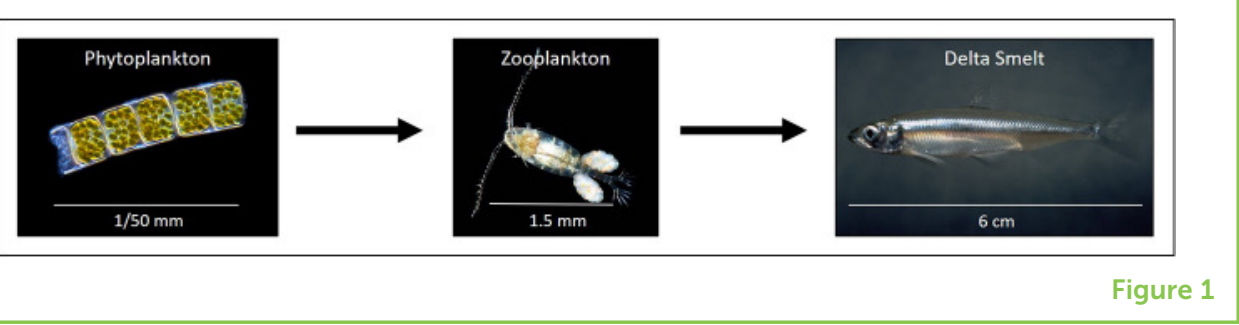

humans changed the ecosystem, the Delta was a complex habitat of interconnected freshwater tidal marshes and floodplains, which is now lost. This complex habitat supported many fish and plankton species [4]. However, there are two places in the Delta, the Yolo Bypass, and the Cache Slough Complex, where freshwater still enters tidal marshes and floodplains still resemble the places where delta smelt once lived (Figure 3).

The Yolo Bypass and Cache Slough Complex together are a huge floodplain and tidal marsh, $\sim 61 \mathrm{~km}$ long, with an area of $240 \mathrm{~km}^{2}$-the same as 33,613 soccer fields! This huge place produces a lot of phytoplankton, which move downstream to the Sacramento River when water flow increases during winter and spring [5]. Because of this, the Yolo Bypass would be a good place for fish, including the delta smelt, to live [6]. However, delta smelt and other native fish cannot live in the Yolo Bypass and Cache Slough Complex during summer and fall, because the water temperature is too warm. But what if food could be moved from the Yolo Bypass and Cache Slough Complex to the places where delta smelt do live during summer and fall?

\section{A FISH-FOOD FACTORY IN THE FLOODPLAIN}

In 2011, scientists started monitoring the food web of the Yolo Bypass and Cache Slough Complex to learn how much phytoplankton and zooplankton exists there throughout the year and how it changes from year to year. In 2011 and 2012, there was a lot of water flowing through this huge floodplain during summer and fall. The water came from rice farms upstream of the Yolo Bypass, and it triggered an explosion of fish food in the floodplain! The water that passed through the floodplain into the Sacramento River moved lots of phytoplankton and zooplankton with it. Scientists wondered if they could move that nutritious water from the floodplain to the river in summer and fall, to feed the fish. So, with local farmers and water engineers, they developed a plan to send river or farm water through the Yolo Bypass in the summer and fall, to deliver food to hungry delta smelt and other fishes living in the Sacramento River downstream from the floodplain (Figure 3). But does this plan really work? 
Figure 2

(A) Before the Gold Rush, the San Francisco Estuary had many floodplains and tidal wetlands where fish and plankton lived. $(B, C)$ Since the Gold Rush, people have developed the Estuary for their own use, by building channels and weirs for flood control and water delivery to cities and farms.

(D) People have also brought in invasive species, like the freshwater clam Corbicula fluminea, which occupy the Estuary and eat plankton (Image credits: drawing of estuary from Sacramento Archives \& Museum Collection Center, Eleanor McClatchy Collection 1982/004/0100. Freshwater clam, Center for Lakes and Reservoirs, Flickr, Creative commons license. Photos of farmland and weir from California Department of Water Resources).

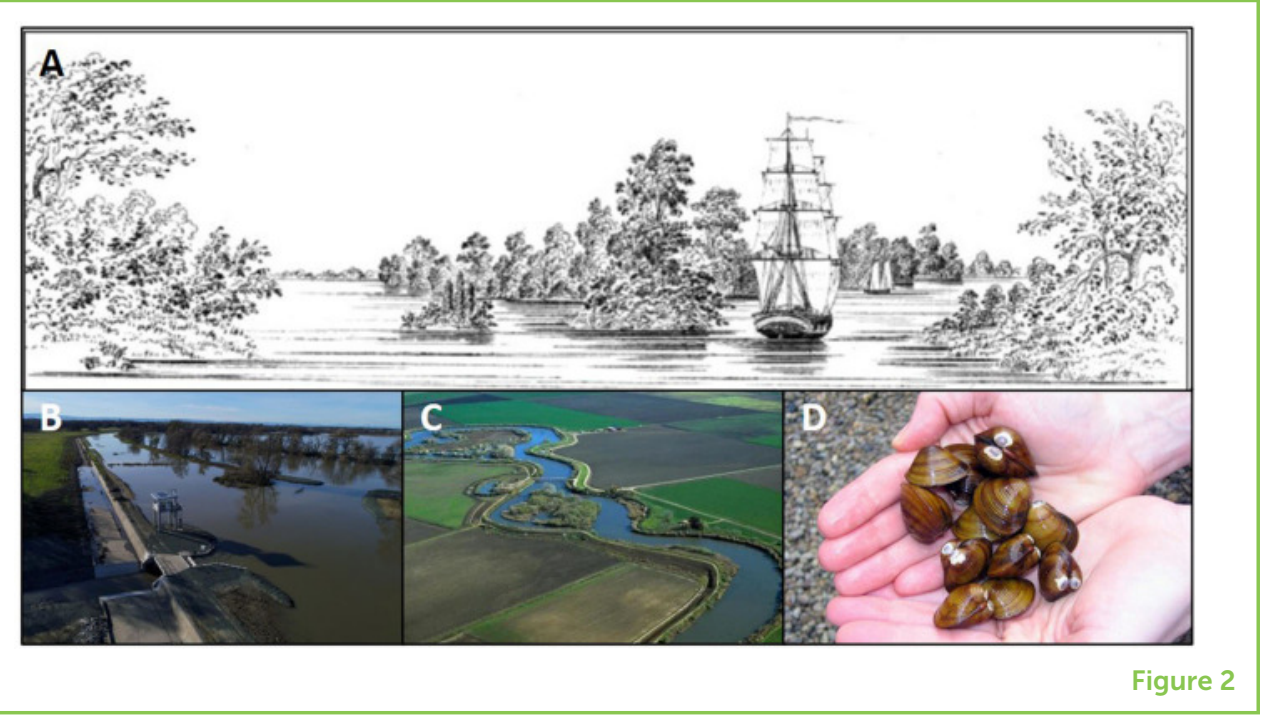

\section{DELIVERING FISH FOOD TO DELTA SMELT}

Scientists worked with water engineers to test their food-delivery plan in 2016, 2018, and 2019. Engineers used a system of pumps, canals, and weirs to move large amounts of water into the floodplain, while scientists studied the water quality and the amounts of phytoplankton and zooplankton that grew in the floodplain and downstream in the Sacramento River. In 2016, river water moved through this system, from upstream of the Yolo Bypass through the floodplain, during the summer. In 2018 and 2019, water moved from rice fields into the Yolo Bypass during the rice harvest season in summer and fall.

From this three-year study, scientists found that the food-delivery plan, which they called the North Delta Flow Action, was successful in delivering plankton from the Yolo Bypass and Cache Slough Complex to the fish living downstream in the Sacramento River. The 2016 food delivery was especially successful, because it resulted in growth of phytoplankton downstream in the lower Sacramento River, including a type of phytoplankton called diatoms, which are very nutritious for zooplankton. More zooplankton were also found downstream from the floodplain, precisely where the delta smelt like to live during the summer and fall. In 2018 and 2019, the food-delivery system was less efficient than in 2016, meaning that less food was delivered during summer and fall. However, there was still more fish food in the lower Yolo Bypass and Cache Slough Complex than before the food-delivery system was implemented.

\section{THE FUTURE OF A SUCCESSFUL FISH FOOD-DELIVERY SYSTEM}

Scientists are still studying the effects of the North Delta Flow Action, and they plan to continue it for many more years. Producing food in 
Figure 3

The Yolo Bypass (a tidal floodplain) and Cache Slough Complex (a tidal wetland) are unique places in the San Francisco Estuary because they produce lots phytoplankton and zooplankton. In summer and fall, delta smelt live downstream in the Sacramento River where food has become scarce. Scientists developed a fish food-delivery system that sends river or farm water through the Yolo Bypass to deliver food to delta smelt and other fish downstream, in the Sacramento River [Photo credits: zooplankton photo by Jeff Cordell (USGS), phytoplankton photo by Alexander Klepnev (licensed under Creative Commons Attribution 4.0 International), smelt photo by René Reyes (USBR). Yolo Bypass, Cache Slough Complex, and water channel photos courtesy of California Department of Water Resources. Map of California form US Geological Survey].

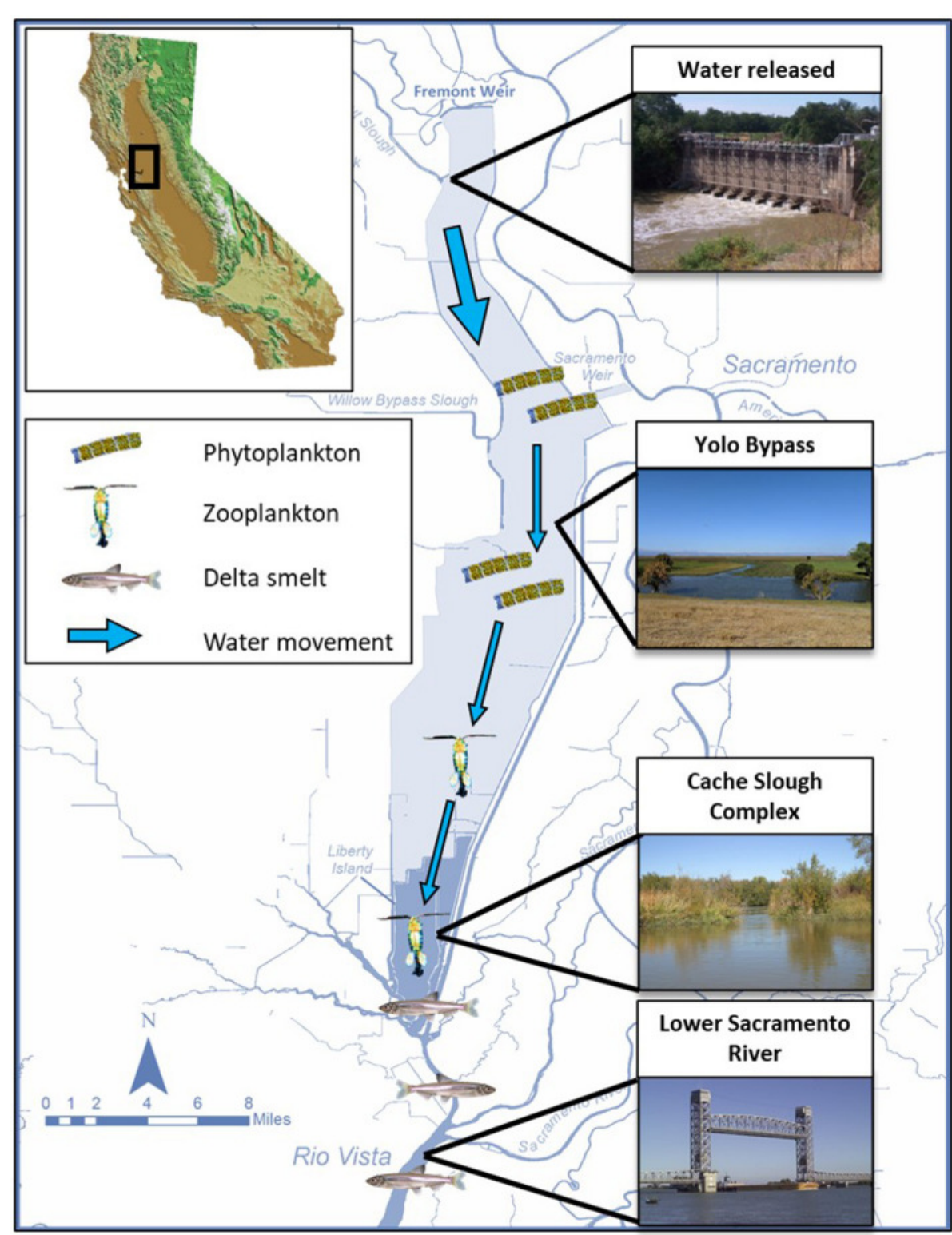

Figure 3

the floodplain and delivering it to delta smelt and other fish species may help these fishes survive and thrive into the future. After all the destruction that humans have caused in the San Francisco Estuary and the Sacramento-San Joaquin Delta, we need to make sure that we do everything we can to protect delta smelt and other important species from becoming extinct.

\section{ACKNOWLEDGMENTS}

We would like to acknowledge Ted Sommer for his contributions to starting the North Delta Flow Action and food web monitoring in the Yolo Bypass. We also thank our project collaborators, Jim Orlando with US Geological Survey, Frances Wilkerson with San Francisco 
State University, and Michael MacWilliams with Anchor QEA. Lastly, managed flow actions would not be possible without scientists and engineers within California Department of Water Resources, as well as local landowners, reclamation districts, and other stakeholders.

\section{ORIGINAL SOURCE ARTICLE}

Frantzich, J. Sommer, T., and Schreier, B. 2018. Physical and Biological Responses to Flow in a Tidal Freshwater Slough Complex. San Franc Estuary Watershed Sci. 16:3. doi: 10.15447/sfews.2018v16iss1/art3

\section{REFERENCES}

1. Brown, L. R., Kimmerer, W., Conrad, J. L., Lesmeister, S., and Mueller-Solger, A. 2016. Food webs of the delta, suisun bay, and suisun marsh: an update on current understanding and possibilities for management. San Franc Estuary Watershed Sci. 14:4. doi: 10.15447/sfews.2016v14iss3art4

2. Sommer, T., Armor, C., Baxter, R., Breuer, R., Brown, L., Chotkowski, M., et al. 2007. The collapse of pelagic fishes in the epper San Francisco estuary. Fisheries. 32:271-7. doi: 10.1577/1548-8446(2007)32[270:TCOPFI]2.0.CO;2

3. Morais, P., Encarnação, J. P., Teodósio, M. A., Dias, E. (accepted). Aliens from an underwater world. Front Young Minds.

4. Moyle, P. B., Bennett, W. A., Fleenor, W. E., and Lund, J. R. 2010. Habitat variability and complexity in the upper San Francisco estuary. San Franc Estuary Watershed Sci. 8:7. doi: 10.15447/sfews.2010v8iss3art1

5. Lehman, P. W., Sommer, T., and Rivard, L. 2008. The influence of floodplain habitat on the quantity and quality of riverine phytoplankton carbon produced during the flood season in San Francisco estuary. Aquat Ecol. 42:363-78. doi: 10.1007/s10452-007-9102-6

6. Mahardja, J. B., Hobbs J. A., Ikemiyagi, N., Bejamin, A., and Finger, A. J. 2019. Role of freshwater floodplain-tidal slough complex in the persistence of the endangered delta smelt. PLOS ONE. 14:e0208084.

doi: 10.1371/journal.pone.0208084

SUBMITTED: 29 September 2020; ACCEPTED: 16 August 2021;

PUBLISHED ONLINE: 10 September 2021.

EDITED BY: Pedro Morais, University of Algarve, Portugal

CITATION: Twardochleb L, Dixit L, Bedwell M, Davis B and Frantzich J (2021) Delivering Food to Hungry Fish in the San Francisco Estuary. Front. Young Minds 9:611957. doi: 10.3389/frym.2021.611957

CONFLICT OF INTEREST: The authors declare that the research was conducted in the absence of any commercial or financial relationships that could be construed as a potential conflict of interest. 

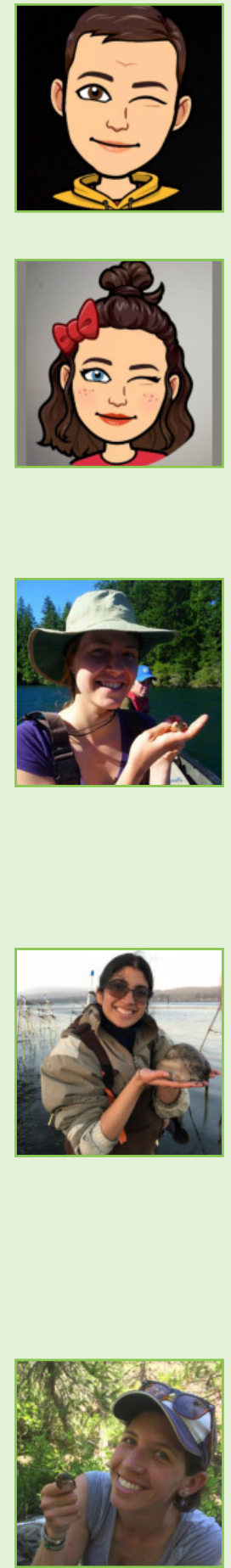

COPYRIGHT @ 2021 Twardochleb, Dixit, Bedwell, Davis and Frantzich. This is an open-access article distributed under the terms of the Creative Commons Attribution License (CC BY). The use, distribution or reproduction in other forums is permitted, provided the original author(s) and the copyright owner(s) are credited and that the original publication in this journal is cited, in accordance with accepted academic practice. No use, distribution or reproduction is permitted which does not comply with these terms.

\section{YOUNG REVIEWERS}

\section{DARIO, AGE: 14}

My name is Dario. I live in a small village in Austria. It is full of nature so in my freetime I like to go out with my dogs or climb trees. My parents are both biologist so I got into biology pretty early.

\section{VALERIE, AGE: 13}

I am in 8th grade of a middle school in Austria. My hobbies are horseback riding, skating, and dancing. I have got a very old cat and we are getting a dog soon. I also like meeting my friends and listening to some music.

\section{AUTHORS}

\section{LAURA TWARDOCHLEB}

Laura Twardochleb is a Senior Environmental Scientist Specialist with California Department of Water Resources. She leads monitoring of the effects of the North Delta Flow Action on the Delta food web. Previously, she researched how climate change alters the life cycles of freshwater insects and other organisms in freshwater food webs. She has also studied the impacts of invasive species and urban development on lake food webs. When not working, she enjoys running and hiking with her dog. *laura.twardochleb@water.ca.gov

\section{LEELA DIXIT}

Leela Dixit is an early career scientist working with California Department of Water Resources as a Fish and Wildlife Scientific Aid. She works with different scientists on projects focused on the San Francisco Estuary habitat, including salmon and smelt resiliency. She graduated from U.C. Davis in 2018 with a Bachelor of Science degree in Evolution, Ecology, and Biodiversity. She has worked in a variety of fields including microbiology, marine ecology, aquatic toxicology, and outdoor education. Outside of the lab, Leela enjoys playing video games, collecting houseplants, and taking care of her hermit crab.

\section{MALLORY BEDWELL}

Mallory Bedwell is interested in using genetic techniques to help with management and conservation of species. In the past, she studied how different species of amphibians evolved. Most recently, she researched how DNA released into the environment, called eDNA, from yellow-legged frogs can be used to detect them in streams and lakes. At California Department of Water Resources, she helps collect 

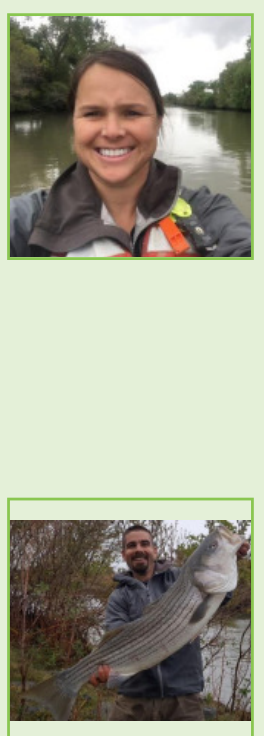

samples to examine the overall state of the Yolo Bypass, including water quality, zooplankton, and fish. She plans to use eDNA monitoring techniques to look for rare fish and to better understand zooplankton communities.

\section{BRITTANY DAVIS}

Brittany Davis is a scientist and Environmental Program Manager for the California Department of Water Resources. Her work focuses on fish and their habitats in the San Francisco Estuary. She works on projects that help us understand how and why changes to the environment hurt fish. She works with other scientists to devise actions that will improve habitats for fish and help prevent extinction of delta smelt. Previously, she researched how climate change might affect fish in our oceans, near beaches, and in Antarctica. When she is not working, she enjoys outdoor adventures with her family and dog.

\section{JARED FRANTZICH}

Jared Frantzich is a Senior Environmental Scientist Supervisor for the California Department of Water Resources. He currently helps to manage over 40 continuous water quality stations throughout the San Francisco Estuary that help provide important data to both water managers and scientists. These stations focus on understanding changes in Estuary water quality that result from habitat restoration actions, water operations, and changing climate conditions. Previously, he spent years researching fish and associated seasonal food-web conditions in the Yolo Bypass floodplain habitat. When he is not at work, he enjoys hunting and spending time on his boat, fishing with his oldest son. 